\title{
Pengaruh Abu Cangkang Sawit Terhadap Kuat Tekan Dan Kuat Lentur Batubata
}

\section{The Effect Of Palm Shell Ash To The Compressive And Flexural Strength Of The Brick}

\author{
Herman dan ${ }^{1}$ Rolly $\mathbf{I}^{2}$ \\ Fakultas Teknik Sipil dan Perencanaan Institut Teknologi Padang \\ Kampus Jln. Gajah Mada Kandis Nanggalo Padang \\ e-mail : hermanmt58@gmail.com
}

Naskah Disetujui : 04-02-2018

\begin{abstract}
This research was conducted to increase the value of compreive strength by adding palm shell ash to the base soil of brick. The palm oil shell was got from the result of the disposal of Incasari Raya Factory Damasraya. The soil as the basic material of the brick was got from the brick's manufactory Gunung Sariak Padang. The persentage of palm shell ash in the soil mixture was $0 \%, 5 \%, 15 \%$ and $25 \%$ from the soil dry weight. The test consisted of physical properties test and mechanical properties test. The physical properties test consisted of water content test, spesific gravity test, Atterberg limit test, and grain size analysis test.The mechanical properties test consisted of compaction test, compressive strength test and flexural strength test. The water content in manufacture brick was $0,85 \% \gamma_{d}$ maximum on wet side optimum of the soi. All the process of the brick is manufactured with manual fabrication. The result of the test showed that the values of spesific gravity (Gs), plastic limit (PL), shrinkage limit (SL),maximum dry density, optimum of water content, and compressive strength of brick increased. Mean while the liquid limit (LL), passing of sieve no. 200 in three days care, plastic index (PI), decreased. For flexural strength, at first increased, along with addition percentage from palm shell ash, this value inclined decreased. The optimum result was got 5\% palm shell ash in the soil mixture.
\end{abstract}

Key note : brick, physical, mechanical, compressive strength, flexural strength, optimum

Abstrak

Untuk meningkatkan nilai kuat tekan batubata, dilakukanlah penelitian dengan menambahkan abu cangkang sawit dalam tanah dasar pembuatan batubata. Cangkang kelapa sawit diambil dari hasil buangan Pabrik Incasari Raya Damasray. Tanah sebagai bahan utama pembuatan batubata, didatangkan dari industri pembuatan batubata Gunung Sariak Padang. Persentase abu cangkang sawit dalam campuran tanah adalah $0 \%, 5 \%, 15 \%$ dan $25 \%$ dari berat kering tanah. Pengujian terdiri dari uji sifat fisis dan sifat mekanis. Uji sifat fisis terdiri dari uji kadar air, spesific gravity, batas-batas Atterberg dan uji saringan. Uji sifat mekanis diantaranya uji pemadatan,uji kuat tekan dan uji kuat lentur. Kadar air pembuatan batubata ditetapkan $0,85 \gamma_{\mathrm{d}}$ maksimum tanah pada sisi basah optimum. Pembuatan batubata dilakukan secara manual. Hasil pengujian menunjukan bahwa, pencampuran abu cangkang sawit terhadap tanah menyebabkan nilai-nilai specific gravity (Gs), batas plastis (PL), batas susut (SL), berat volume kering maksimum ( $\gamma_{\mathrm{d}}$ maks), kadar air optimum $\left(\mathrm{w}_{\mathrm{opt}}\right)$ tanah, dan kuat tekan batubata meningkat. Sedangkan nilai-nilai batas cair (LL), lolos saringan no. 200 pada perawatan 3 hari, indeks plastis (PI) menurun. Untuk nilai kuat lentur pada awalnya terjadi peningkatan, dan seiring dengan penambahan persentase abu cangkang sawit selanjutnya, nilai ini cenderung menurun. Hasil optimum penelitian ini diperoleh pada 5\% abu cangkang sawit dalam campuran tanah.

Kata - kata kunci : batubata, fisis, mekanis, kuat tekan, kuat lentur, optimum

\section{PENDAHULUAN}

Batubata adalah bahan bangunan

yang banyak dipakai oleh masyarakat sebagai bahan konstruksi seperti untuk dinding pada bangunan bertingkat, untuk dinding rumah tinggal, dinding penahan tanah, pagar, saluran, pondasi dan sebagainya. Pada bangunan gedung batubata 
digunakan sebagai bahan dinding pengisi dalam struktur rangka. Telah banyak pengujian dan analisa yang mendapatkankan bahwa dinding bata dalam struktur rangka beton bertulang berkontribusi dalam menahan beban gempa (Maidiawati dkk, 2016). Pada konstruksi lain batubata juga memberikan kontribusi kekuatan dan kekakuan yang besar.

Batubata yang umum digunakan adalah batubata merah dengan harga cukup murah dan mudah didapat. Bata merah terbuat dari tanah liat dan beberapa mineral lain yang dibentuk dalam ukuran tertentu, lazimnya berukuran $24 \times 12 \times 6 \mathrm{~cm}$, kemudian dikeringkan di bawah sinar matahari, selanjutnya setelah melewati proses pengeringan maka masuk dalam tahap pembakaran dalam tungku untuk membuat bata menjadi kuat. Bata merah yang bagus, biasanya keras, tahan api, dan tahan terhadap pelapukan (Setiawan D, 2016). Bata merah yang diproduksi oleh masyarakat kebanyakan masih memiliki mutu yang belum mencapai yang diharapkan. Mutu batubata dinyatakan dalam nilai kuat tekan masih berkisar di bawah 5,0 MPa. Nilai ini masih belum memenuhi syarat untuk konstruksi bangunan terutama di daerah rawan gempa.

Selain mempunyai kuat tekan yang tinggi juga diperlukan batubata dengan kuat lentur yang besar. Untuk mendapatkankan batubata merah dengan mutu yang lebih baik yaitu mempunyai kuat tekan dan kuat lentur yang besar, maka diperlukan inovasi terhadap material pembuat batubata. Dalam penelitian ini dilakukan pengujian untuk mengetahui pengaruh abu cangkang sawit dalam campuran tanah pembuat batubata terhadap kuat tekan dan kuat lentur batubata.

\section{TINJAUAN PUSTAKA}

Penelitian tentang inovasi campuran tanah liat (clay) sebagai bahan pembuatan batubata dengan material lain seperti ; abu sekam padi, zeolit, serbuk gergaji dan abu vulkanik untuk mendapatkan hasil batubata yang baik telah dilakukan oleh sejumlah peneliti. Penambahan abu sekam padi (silica RHA) pada batubata Payakumbuh dapat meningkatkan kuat tekan batubata merah dengan persentase abu sekam padi sebesar 15\% (Hernandes,R., 2012). Selain untuk nilai kuat tekan, pencampuran abu sekam padi $(R H A)$ pada batubata dengan variasi tekanan cetak dapat meningkatkan nilai density dan memperkecil porositas dan penyerapan air (Indra, A., 2013). Penggunaan bahan tambahan abu sekam padi berpengaruh terhadap peningkatan sifat mekanis batubata. Kuat tekan batubata meningkat, sedangkan daya serap air menurun (Munasih dkk, 2016).

Dengan menggunakan campuran zeolit kedalam tanah bahan pembuatan batubata , hasil yang dicapai dapat memenuhi Standar Nasional Indonesia (SNI), nilai berat jenis tanah campuran menurun, sedangkan nilai kuat tekan batubata tanpa 
pembakaran dan dengan pembakaran menunjukan perbaikan. Hasil paling baik dicapai pada kadar campuran 10\% - 12\% zeolit dalam tanah pembuatan batubata (Fernanda A, dkk, 2012).

Penambahan serbuk gergaji 10\% terhadap tanah lempung bahan pembuatan batubata, menghasilkan batubata yang lebih ringan beratnya dan mampu meningkatkan produktifitas karena keretakannya $0 \%$, tetapi memberikan kekuatan yang tidak berbeda secara signifikan dengan tanpa campuran (Handayani, S. 2010).

Penggunaan abu vulkanik pada batubata menghasilkan berat jenis yang lebih ringan dibandingkan batubata normal, dengan kuat tekan masuk dalam kelas mutu 50 dan nilai daya serapan air berada dibawah standar nilai maksimal daya resapan air yaitu sebesar 20\% sesuai SNI 15-2094-2000 (Raharjo, MT, dkk, 2015).

Campuran abu cangkang sawit dalam tanah lempung dapat meningkatkan daya dukung tanah lempung, dengan jumlah abu cangkang sawit yang paling efektif adalah $6 \%$ dari campuran tanah liat dan dengan waktu pemeraman $0,1,4.7$ dan 14 hari (Surta RNP., 2012).

Berdasarkan dari hasil penelitianpenelitian di atas dapat diprediksi bahwa abu cangkang sawit dapat digunakan untuk meningkatkan nilai kuat tekan batubata.

\section{Abu Cangkang Sawit}

Abu cangkang sawit merupakan hasil sampingan dari pembakaran cangkang kelapa sawit. Abu ini biasanya dibuang dekat pabrik pengolah kelapa sawit sebagai limbah padat dan tidak dimanfaatkan. Akibatnya keberadaan abu ini sangat banyak disekitar pabrik. Dari penelitian yang telah dilakukan, abu cangkang sawit ini banyak mengandung silika $\left(\mathrm{SiO}_{2}\right)$. Selain itu abu cangkang sawit juga mengandung $\mathrm{Al}_{2} \mathrm{O}_{3}, \mathrm{Fe}_{2} \mathrm{O}_{3}, \mathrm{CaO}$ dan unsur-unsur lain seperti yang ditunjukan dalam Tabel 1.

Tabel 1. Unsur kimia abu cangkang sawit

\begin{tabular}{|c|c|}
\hline Unsur Kimia & Persentase (\%) \\
\hline $\mathrm{SiO}_{2}$ & 58,02 \\
\hline $\mathrm{Al}_{2} \mathrm{O}_{3}$ & 8,7 \\
\hline $\mathrm{Fe}_{2} \mathrm{O}_{3}$ & 2,6 \\
\hline $\mathrm{CaO}$ & 12,56 \\
\hline $\mathrm{MgO}$ & 4,23 \\
\hline $\mathrm{Na}_{2} \mathrm{O}$ & 0,41 \\
\hline $\mathrm{K}_{2} \mathrm{O}$ & 0,72 \\
\hline $\mathrm{H}_{2} \mathrm{O}$ & 1,97 \\
\hline Hasil Pijar & 8,59 \\
\hline
\end{tabular}

(Sumber ; Hutahaean, 2007)

Apabila unsur silika $\left(\mathrm{SiO}_{2}\right)$ dan kapur bebas $(\mathrm{CaO})$ yang terkandung dalam abu cangkang sawit maupun dalam tanah lempung bahan pembuat batubata bereaksi, maka akan membentuk suatu gel yang kuat dan keras yaitu kalsium silikat hydrat (CSH) yang mengikat butir-butir atau partikel tanah (Diamond \& Kinter,1965 dalam Ingles dan Metcalf, 1972). Mekanisme reaksi yang terjadi adalah sebagai berikut (Tjokrodimuljo,1995 dalam Fathani,1998);

$$
\mathrm{CaO}+\mathrm{H}_{2} \mathrm{O} \rightarrow \mathrm{Ca}(\mathrm{OH})_{2}+\text { panas }
$$

dengan : 
$\mathrm{CaO}=$ kalsium oksida (kapur bebas)

$\mathrm{Ca}(\mathrm{OH})_{2}=$ kalsium hidroksida (kapur padam)

Reaksi pozzolanik berikutnya adalah

$$
\begin{aligned}
& \mathrm{Ca}(\mathrm{OH})_{2}+\mathrm{SiO}_{2} \rightarrow \mathrm{C}-\mathrm{S}-\mathrm{H} \\
& \mathrm{Ca}(\mathrm{OH})_{2}+\mathrm{Al}_{2} \mathrm{O}_{3} \rightarrow \mathrm{C}-\mathrm{A}-\mathrm{H}
\end{aligned}
$$

dengan :

$\mathrm{SiO}_{2}=$ silica dioksida

$\mathrm{Al}_{2} \mathrm{O}_{3}=$ aluminium oksida

$\mathrm{CSH}=$ kalsium silikat hidrat berupa gel

$\mathrm{CAH}=$ kalsium aluminat hidrat berupa gel

Gel silika dan gel aluminium bereaksi dengan segera melapisi dan mengikat partikel lempung dan menutup pori-pori tanah, sehingga butiran dari tanah lempung mejadi lebih kasar dan tahan terhadap resapan air.

\section{Tanah Liat / Lempung (clay)}

Tanah lempung (clay) adalah jenis tanah yang bersifat kohesif dan plastis, terdiri dari partikel mikroskopis dan submikroskopis yang berbentuk lempengan-lempengan pipih dan mempunyai permukaan khusus. Lempung didefinisikan sebagai golongan partikel yang mempunyai ukuran kurang dari 0,002 mm (=2 mikron) (Das,1998) dan sangat tergantung pada komposisi mineral dan unsur-unsur kimianya. Umumnya, terdapat kira-kira 15 macam mineral yang diklasifikasikan sebagai mineral lempung (Kerr,1959 dalam Hardiyatmo,2012).

Tanah lempung mempunyai partikelpartikel tertentu yang menghasilkan sifatsifat plastis pada tanah bila dicampur dengan air (Grim,1953 dalam Das, 1998). Sifat plastis lempung adalah akibat eksistensi air lapisan ganda. Air lapisan ganda pada bagian paling dalam yang sangat kuat melekat pada partikel lempung, disebut air serapan (adsorbed water). Hubungan mineralmineral lempung dengan air serapan, memberikan bentuk dasar dari susunan tanah. Tiap partikel lempung saling terikat lewat lapisan air serapan (Hardiyatmo, 2012).

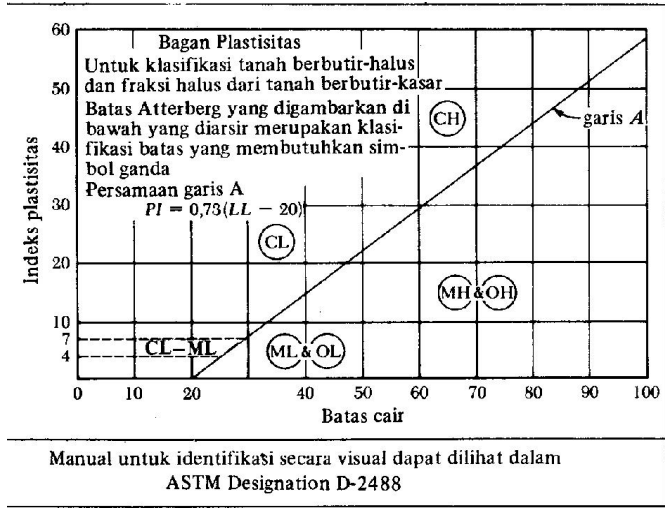

Gambar 1. Bagan Plastisitas klasifikasi USCS (Das, 1998)

ASTM D-653 memberikan batasan bahwa secara fisik ukuran lempung adalah partikel yang berukuran antara 0,002 $\mathrm{mm}$ sampai $0,005 \mathrm{~mm}$. Tanah ini digolongkan kedalam tanah berbutir halus menurut USCS.

\section{Kepadatan Tanah}

Tingkat kepadatan tanah diukur dari berat volume kering $\left(\gamma_{d}\right)$ nya . Bila air ditambahkan kepada tanah yang dipadatkan, partikel-partikel tanah lebih mudah bergeser merapat dan padat, bila kadar air tanah mencapai harga tertentu, adanya penambahan kadar air justru menurunkan kepadatan tanah. Hal ini karena air mengisi 
rongga pori yang sebelumnya diisi oleh butiran tanah. Kadar air pada saat berat volume kering mencapai maksimum disebut kadar air optimum $\left(\mathrm{W}_{\mathrm{opt}}\right)$. Hubungan antara kadar air (w) dengan berat volume kering $\operatorname{tanah}\left(\gamma_{\mathrm{d}}\right)($ Gambar 2).

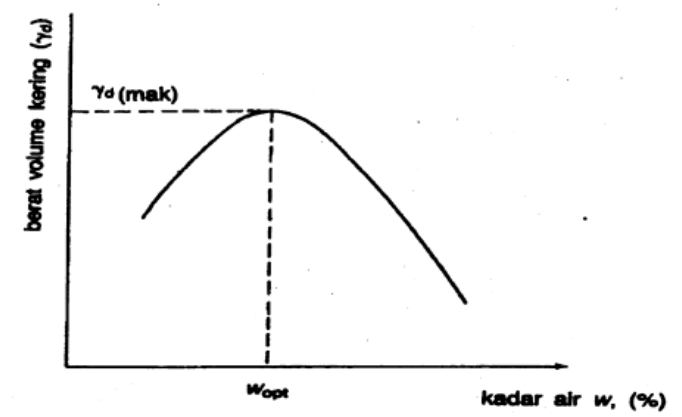

Gambar 2. Kurva hubungan kadar air (w) dengan berat volume kering $\left(\gamma_{d}\right)$

Posisi kadar air tanah lempung yang dipadatkan didasarkan ;

a. Sisi kering optimum (dry side of optimum) yaitu kadar air yang kurang dari kadar air optimumnya.

b. Dekat optimum yaitu kadar air yang kurang lebih dekat optimumnya

c. Optimum.

d. Sisi basah optimum (wet side of optimum) yaitu kadar air yang lebih dari kadar air optimumnya.

\section{METODOLOGI}

Penelitian dilakukan di Laboratorium

Teknik Sipil Institut Teknologi Padang. Tanah lempung sebagai bahan pembuatan batu bata didatangkan dari tempat pembuatan batu bata, yaitu dari desa Gunung Sariak Padang. Pembuatan batubata dilakukan secara manual. Kadar air ditetapkan $85 \% \gamma_{d}$ maksimum pada sisi basah optimum. Ketetapan ini diambil karena pada kondisi $100 \% \gamma_{\mathrm{d}}$ maksimum, kondisi tanah masih berada dalam keadaan kaku, sehingga menyulitkan pembuatan bata secara manual.

Cangkang sawit diambil dari tempat pengolahan kelapa sawit PT. Incasari Raya Damasraya. Pembakaran cangkang sawit dilakukan di-Laboratorium Teknik Mesin Institut Teknologi Padang dengan suhu > $600^{\circ} \mathrm{C}$. Batubata dengan campuran abu cangkang sawit dibuat dengan variasi pesentase abu cangkang sawit adalah $0 \%$, $5 \%, 15 \%, 25 \%$ terhadap berat kering tanah lempung.

Pembakaran batubata yang telah dibuat dilakukan di Laboratorium Teknik Mesin Institut Teknologi Padang dengan suhu ditetapkan $700^{\circ} \mathrm{c}-1000^{\circ} \mathrm{c}$. Sebelum pembakaran batubata dikeringkan terlebih dahulu dibawah sinar matahari. Uji sifat fisis dan uji sifat mekanis dilakukan pada bahan tanah pembuatan batu bata, baik tanah asli maupun tanah yang telah dicampur dengan berbagai variasi persentase abu cangkang sawit. Sedangkan pada batu bata sendiri dilakukan uji tekan dan uji lentur. Langkahlangkah penelitian ditunjukan pada bagan alur penelitian Gambar 3. Uji sifat fisis dan jumlah sampel dari tanah bahan pembuat batubata, baik tanah asli maupun tanah telah dicampur dengan berbagai persentase abu cangkang sawit seperti padaTabel 2, dan Tabel 3 uji sifat mekanis tanah dan uji kuat tekan dan kuat lentur batubata. 


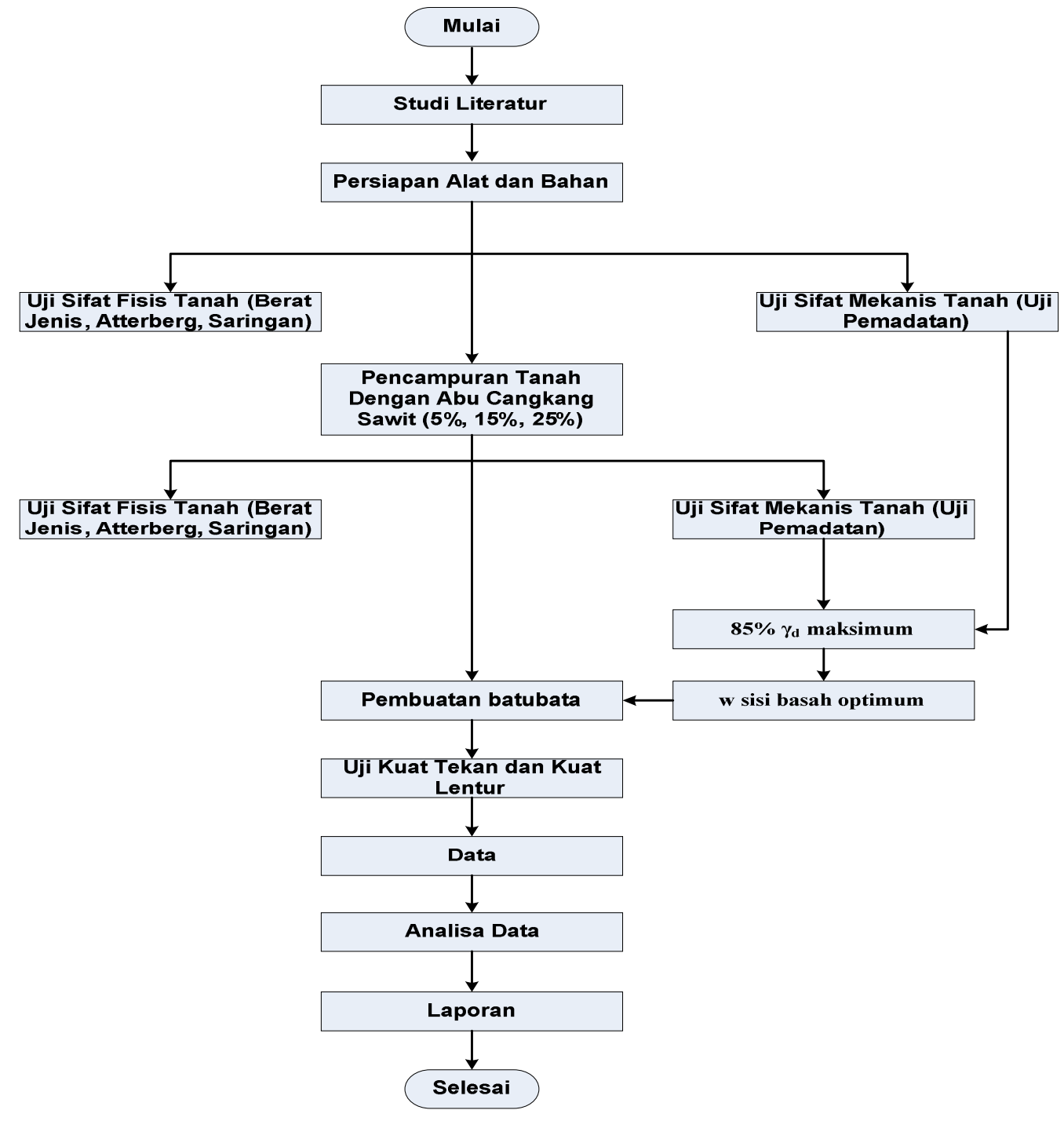

Gambar 3. Bagan Alur Penelitian

Tabel 2. Pemeriksaan sifat fisis tanah

\begin{tabular}{|c|l|c|c|}
\hline No & \multicolumn{1}{|c|}{ Jenis Pengujian } & Standar Pengujian & Jumlah sampel \\
\hline 1 & Analisis saringan & ASTM D421-58 & 4 \\
\hline 2 & Hidrometer & ASTM D422-63 & 4 \\
\hline 3 & Pemeriksaan nilai specific gravity & ASTM D8554-58 & 8 \\
\hline 4 & Penentuan kadar air & ASTM D2216-98 & 8 \\
\hline & Pemeriksaan nilai Batas-batas Konsistensi: & ASTM D423-66, & \\
5 & $\bullet \quad$ Batas Cair & D424-59 dan ASTM & 4 \\
& $\bullet \quad$ Batas Plastis & D427-61 & 8 \\
& $-\quad$ Batas Susut & \\
\hline
\end{tabular}

Tabel 3. Pemeriksaan sifat Mekanis tanah

\begin{tabular}{|c|c|c|c|}
\hline No & Jenis Pengujian & Standar Pengujian & Jumlah sampel \\
\hline 1 & Pemadatan standar (Proctor) & ASTM D698-78 & 4 \\
\hline 2 & Uji kuat tekan batubata & & 12 \\
\hline 3 & Uji kuat lentur batubata & & 12 \\
\hline
\end{tabular}


HASIL DAN PEMBAHASAN

Hasil

\section{Pengujian Material}

\section{Pengujian pendahuluan}

Hasil uji pendahuluan yaitu pemeriksaan sifat-sifat fisis dan sifat-sifat mekanis tanah asli bahan pembuat batubata, juga pemeriksaan sifat fisis abu cangkang sawit. Hasil yang didapat dari penelitian ini ditunjukan dalam Tabel 4, Tabel 5, Tabel 6.

Tabel 4. Hasil pengujian sifat fisis tanah asli

\begin{tabular}{|l|c|}
\hline \multicolumn{1}{|c|}{ Jenis Pengujian } & \\
\hline Kadar air lapangan & $54,50 \%$ \\
\hline Kadar air kering udara & $5,63 \%$ \\
\hline Spesific gravity $(G s)$ & 2,34 \\
\hline Batas cair $(L L)$ & $67,60 \%$ \\
\hline Batas plastis $(P L)$ & $43,27 \%$ \\
\hline Batas susut $(S L)$ & $12,08 \%$ \\
\hline Indeks plastis $(P I)$ & $24,33 \%$ \\
\hline Lolos saringan No. 200 & $87,91 \%$ \\
\hline
\end{tabular}

Tabel 5. Hasil pengujian sifat fisis abu cangkang sawit

\begin{tabular}{|c|c|}
\hline Jenis Pengujian & Hasil \\
\hline Spesific gravity $(G S)$ & 2,70 \\
\hline
\end{tabular}

Tabel 6. Hasil uji sifat mekanis tanah asli

\begin{tabular}{|l|c|}
\hline \multicolumn{1}{|c|}{ Jenis Pengujian } & Hasil \\
\hline Berat volume kering & 1,165 \\
maksimum $\left(\gamma_{\mathrm{d} \text { maks }}\right)$ & $\mathrm{gr} / \mathrm{cm}^{3}$ \\
\hline Kadar air optimum $\left(\mathrm{w}_{\mathrm{opt}}\right)$ & $22,00 \%$ \\
\hline
\end{tabular}

\section{Pengujian pokok}

Pengujian pokok terdiri dari uji sifatsifat fisis maupun pengujian sifat-sifat mekanis dari tanah pembuat batubata, yang telah dicampur berbagai variasi persentase abu cangkang sawit yang hasilnya ditampilkan dalam Tabel 7 dan Tabel 8. Berdasarkan data hasil uji sifat fisis dan sifat mekanis tanah lempung dan abu cangkang sawit, maupun tanah yang telah dicampur dengan berbagai variasi persentase abu cangkang sawit. Dibuatlah batubata dari bahan tanah asli, maupun dari bahan tanah yang telah dicampur dengan berbagai variasi persentase abu cangkang sawit, yaitu 5\%, $15 \%$ dan $25 \%$ dari berat kering tanah lempung pembuat batubata.

Pengujian kuat tekan dan kuat lentur dilakukan untuk sampel batubata seperti ditunjukan dalam Gambar 4. Hasil pengujian kuat tekan dan kuat lentur batubata ditunjukan dalam Tabel 9 dan Tabel 10.

Tabel 7. Hasil uji sifat fisis tanah dicampur dengan abu cangkang sawit

\begin{tabular}{|l|c|c|c|}
\hline \multirow{2}{*}{ Jenis Pengujian } & \multicolumn{3}{|c|}{ Persentase abu cangkang sawit } \\
\cline { 2 - 4 } & $\mathbf{5 \%}$ & $\mathbf{1 5 \%}$ & $\mathbf{2 5 \%}$ \\
\hline Spesific gravity $(G s)$ & 2,36 & 2,38 & 2,39 \\
\hline Batas cair $(L L)$ & $55,15 \%$ & $52,70 \%$ & $49,65 \%$ \\
\hline Batas plastis $(P L)$ & $44,02 \%$ & $45,19 \%$ & $46,50 \%$ \\
\hline Batas susut $(S L)$ & $15,77 \%$ & $25,44 \%$ & $29,69 \%$ \\
\hline Indeks plastisitas $(P I)$ & $11,13 \%$ & $7,51 \%$ & $3,15 \%$ \\
\hline Lolos saringan no. 200 ,perawatan 3 hari & $81,33 \%$ & $76,00 \%$ & $74,60 \%$ \\
\hline
\end{tabular}


Tabel 8. Hasil uji sifat mekanis tanah dicampur dengan abu cangkang sawit

\begin{tabular}{|l|c|c|c|}
\hline \multirow{2}{*}{ Jenis Pengujian } & \multicolumn{3}{|c|}{ Persentase Abu cangkang sawit } \\
\cline { 2 - 4 } & $\mathbf{5 \%}$ & $\mathbf{1 5 \%}$ & $\mathbf{2 5 \%}$ \\
\hline Berat volume kering maksimum $\left(\gamma_{d}\right.$ maks $)$ & $1,23 \mathrm{gr} / \mathrm{cm}^{3}$ & $1,24 \mathrm{gr} / \mathrm{cm}^{3}$ & $1,25 \mathrm{gr} / \mathrm{cm}^{3}$ \\
\hline Kadar air optimum $\left(w_{\text {opt }}\right)$ & $34,17 \%$ & $38,00 \%$ & $38,23 \%$ \\
\hline
\end{tabular}
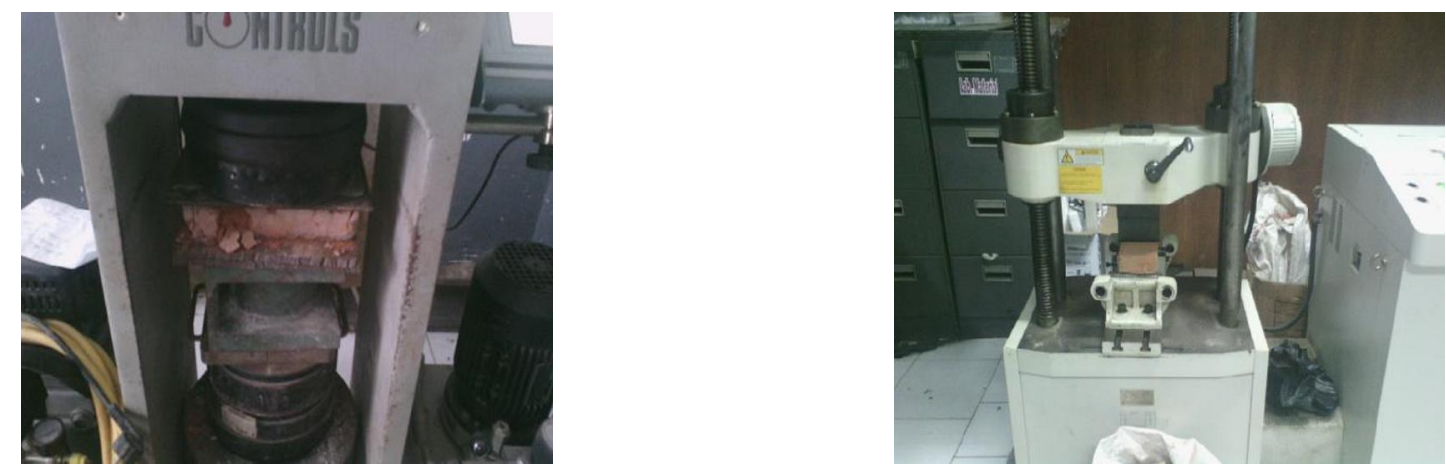

Gambar 4. Pengujian kuat tekan dan kuat lentur batubata

Tabel 9. Hasil uji kuat tekan batubata

\begin{tabular}{|c|c|c|c|}
\hline \multicolumn{2}{|c|}{ Kondisi batubata } & \multirow{2}{*}{$\begin{array}{c}\begin{array}{c}\text { Kuat Tekan } \\
\left(\mathrm{kg} / \mathrm{cm}^{2}\right)\end{array} \\
51,54\end{array}$} & \multirow{2}{*}{$\begin{array}{c}\text { Kuat Tekan } \\
\text { Rata-rata } \\
\left(\mathrm{kg} / \mathrm{cm}^{2}\right)\end{array}$} \\
\hline \multirow{3}{*}{ Bata kondisi asli } & Sampel 1 & & \\
\hline & Sampel 2 & 61,54 & \multirow{2}{*}{62,29} \\
\hline & Sampel 3 & 73,80 & \\
\hline \multirow{3}{*}{ Bata dengan campuran abu 5\% } & Sampel 1 & 94,84 & \multirow{3}{*}{107,21} \\
\hline & Sampel 2 & 117,51 & \\
\hline & Sampel 3 & 109,29 & \\
\hline \multirow{3}{*}{ Bata dengan campuran abu $15 \%$} & Sampel 1 & 114,31 & \multirow{3}{*}{109,43} \\
\hline & Sampel 2 & 95,15 & \\
\hline & Sampel 3 & 118,85 & \\
\hline \multirow{3}{*}{ Bata dengan campuran abu $25 \%$} & Sampel 1 & 167,44 & \multirow{3}{*}{121,20} \\
\hline & Sampel 2 & 115,28 & \\
\hline & Sampel 3 & 80,84 & \\
\hline
\end{tabular}

Tabel 10. Hasil uji kuat lentur batubata

\begin{tabular}{|l|l|c|c|}
\hline \multicolumn{2}{|c|}{ Kondisi batubata } & $\begin{array}{c}\text { Kuat Lentur } \\
\left(\mathrm{kg} / \mathrm{cm}^{2}\right)\end{array}$ & $\begin{array}{c}\text { Kuat Lentur Rata- } \\
\text { rata }\left(\mathrm{kg} / \mathrm{cm}^{2}\right)\end{array}$ \\
\hline \multirow{3}{*}{ Bata kondisi asli } & Sampel 1 & 4,4 & \multirow{2}{*}{3,3} \\
\cline { 2 - 3 } & Sampel 2 & 3,7 & \\
\cline { 2 - 3 } & Sampel 3 & 1,8 & \\
\hline \multirow{3}{*}{ Bata dengan campuran abu 5\% } & Sampel 1 & 6,5 & \multirow{2}{*}{8,97} \\
\cline { 2 - 3 } & Sampel 2 & 10,3 & \\
\cline { 2 - 3 } & Sampel 3 & 10,1 & \multirow{2}{*}{7,86} \\
\hline \multirow{3}{*}{ Bata dengan campuran abu 15\% } & Sampel 1 & 11,7 & \\
\cline { 2 - 3 } & Sampel 2 & 5,5 & \\
\cline { 2 - 3 } & Sampel 3 & 6,4 & \\
\hline
\end{tabular}




\begin{tabular}{|l|l|}
\hline Sampel 1 & 4,2 \\
\hline Sampel 2 & 2,8 \\
\hline Sampel 3 & 3,4 \\
\hline
\end{tabular}

\section{Pembahasan}

\section{Tanah pembuat batu bata}

Butiran tanah yang lolos saringan no 200 mencapai 87,91\%>50\%, menurut Unified Soil Clasification System (USCS), tanah termasuk jenis berbutir halus. Nilai batas cair $(L L)$ tanah $=67,60 \%>50 \%$, hal ini menunjukan tanah termasuk lempung atau lanau dengan plastisitas tinggi, dan jika dilihat dari harga indeks plastisitas $(P I)$ tanah $=24,33 \%$, dan jika nilai indeks plastisitas $(P I)$ ini dihitung berdasarkan persamaan “garis A" (Gambar 1), maka $P I=0,73(67,60$ - 20) $=34,75 \%$. Hasil ini besar dari nilai indeks plastisitas $(P I)$ tanah dari hasil penelitian 24,33\%, hal ini menggambarkan bahwa nilai indeks plastisitas $(P I)$ dari tanah asli bahan pembuat batubata berada dibawah "garis A", sehingga tanah tersebut dapat dimasukankan kedalam kelompok $M H$, atau lanau anorganik dengan plastisitas tinggi.

\section{Karakteristik tanah dengan berbagai variasi campuran abu cangkang sawit}

Hasil uji saringan dari tanah pembuat batubata, maupun tanah yang telah dicampur dengan berbagai variasi persentase abu cangkang sawit seperti Tabel 4. Tabel 7 dan

\section{Gambar 5.}

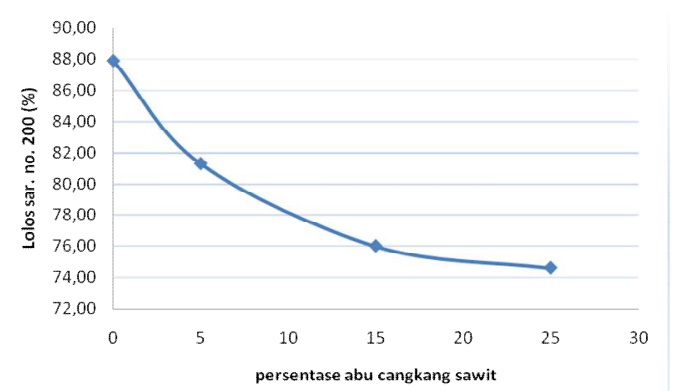

Gambar 5. Pengaruh persentase abu cangkang sawit terhadap fraksi lolos sar. no. 200

Dari kurva dapat dilihat bahwa keberadaan abu cangkang sawit dalam campuran tanah dengan masa perawatan 3 hari dapat menurunkan persentase lolos saringan no. 200 dari tanah. Pada persentase $25 \%$ abu cangkang sawit dalam tanah dapat menurunkan persentase lolos saringan no. 200 sebesar 13,31\% atau $15,14 \%$ dari lolos saringan no .200 tanah asli. Hal ini memberikan gambaran bahwa, keberadaan abu cangkang sawit didalam tanah, memberikan pengaruh terjadinya ikatan antar butiran tanah. Sehingga persentase butiran kasar tanah menjadi lebih meningkat, dan sebaliknya persentase butiran halus menjadi berkurang.

Hasil uji gravitas khusus pada tanah asli maupun tanah yang telah dicampur dengan berbagai variasi persentase abu cangkang sawit menunjukan, nilai ini meningkat seiring dengan bertambahnya 
persentase abu cangkang sawit dalam tanah

Tabel 4, Tabel 7 dan Gambar 6.

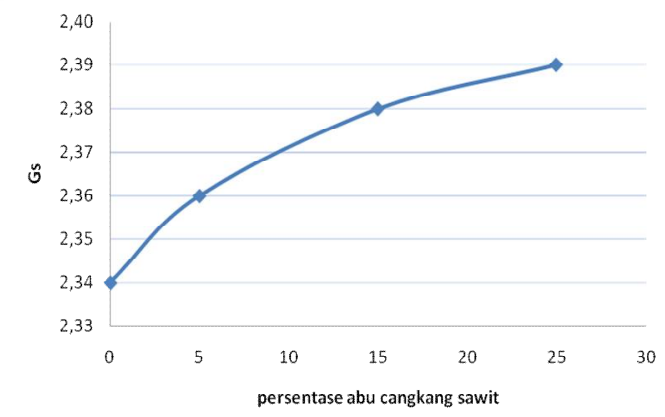

Gambar 6. Pengaruh abu cangkang sawit terhadap nilai $G s$ tanah

Grafik menunjukan, terjadinya peningkatan nilai gravitas khusus tanah seiring dengan meningkatnya persentase abu cangkang sawit dalam kandungan tanah. Pada campuran $25 \%$ abu cangkang sawit didalam tanah, terjadi peningkatan nilai $G s$ sebesar 0,05 atau $2,14 \%$ dari nilai $G s$ tanah asli. Hal ini disebabkan karena nilai $G s$ abu cangkang sawit lebih besar dari nilai Gs tanah asli.

Hasil uji batas-batas Atterberg pada tanah asli maupun tanah yang telah dicampur dengan berbagai variasi persentase abu cangkang sawit seperti Tabel 4, Tabel 7 dan

Gambar 7.

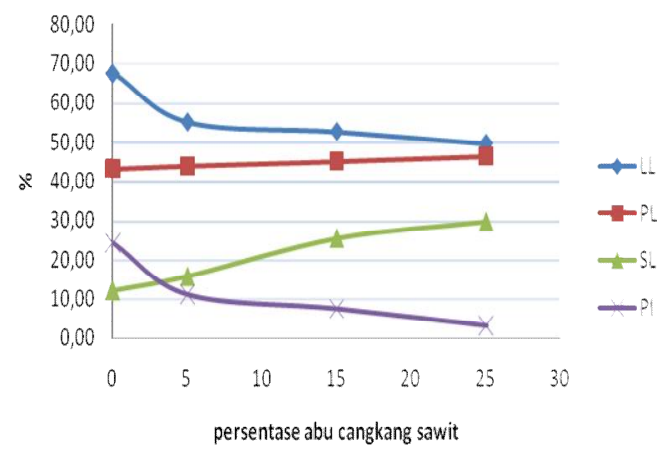

Gambar 7. Pengaruh abu cangkang sawit terhadap nilai batas-batas Atterberg tanah

Nilai batas cair $(L L)$ dan indeks plastisitas $(P I)$ cenderung turun seiring dengan meningkatnya persentase abu cangkang sawit dalam campuran tanah. Pada $25 \%$ abu cangkang sawit dalam campuran tanah, nilai batas cair $(L L)$ turun sebesar $17,95 \%$ atau $26,55 \%$ dari nilai batas cair tanah asli. Nilai indeks plastisitas $(P I)$ turun sebesar $21,18 \%$ atau $87,05 \%$ dari nilai indeks plastisitas tanah asli. Sebaliknya nilai batas plastis $(P L)$ dan nilai batas susut $(S L)$ meningkat. Pada 25\% abu cangkang sawit dalam campuran tanah nilai batas plastis $(P L)$ meningkat sebesar $3,23 \%$ atau $7,46 \%$ dari nilai batas plastis $(P L)$ tanah asli. Nilai batas susut $(S L)$ meningkat sebesar 17,61\% atau $145,78 \%$ dari nilai batas susut $(S L)$ tanah asli.

Menurunnya nilai batas cair $(L L)$ tanah ini seiring dengan meningkatnya persentase abu cangkang sawit didalam tanah disebabkan karena, terjadi adanya ikatan antar butir tanah yang kuat didalam tanah, sehingga sulit tertembus oleh air, akibatnya serapan air oleh tanah menjadi berkurang. Disamping itu dengan meningkatnya butiran kasar tanah, seperti yang ditunjukan oleh hasil uji saringan, persentase butiran halus dalam tanah menjadi berkurang. Akibatnya sifat tanah berbutir halus dalam hal penyerapan air melalui permukaan butiran 
akan berkurang pula, hal ini disebabkan karena luas permukaan butiran tanah mengecil dan tanah menjadi lebih stabil dari perubahan volume, ini dapat dilihat dengan meningkatnya nilai batas susut $(S L)$ tanah.

Berkurangnya nilai batas cair $(L L)$ ini menggambarkan menurunnya plastisitas tanah, hal ini dapat dilihat dari nilai indeks plastisitas $(P I)$ tanah yang turun, dan nilai batas plastis $(P L)$ tanah yang meningkat. Meningkatnya nilai batas plastis tanah ini dikarenakan tanah lebih banyak membutuhkan air untuk mempertahankan keplastisitasnya.

Hasil uji pemadatan menunjukan nilai-nilai kadar air optimum $\left(\mathrm{w}_{\mathrm{opt}}\right)$ dan berat kering maksimum $\left(\gamma_{\mathrm{d}}\right.$ maks $)$ cenderung meningkat seiring dengan bertambahnya kandungan abu cangkang sawit dalam tanah Tabel 6, Tabel 8, Gambar 8 dan Gambar 9.

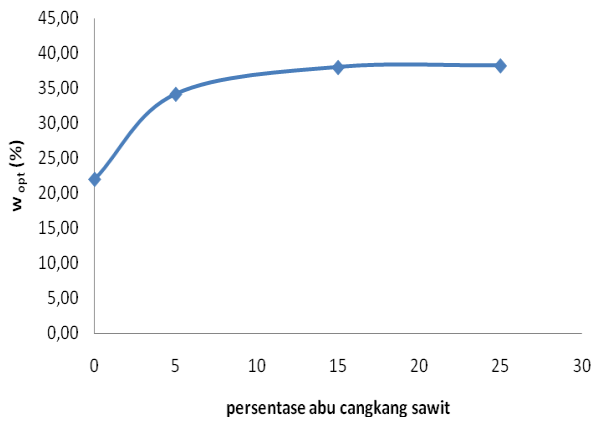

Gambar 8. Pengaruh abu cangkang sawit terhadap kadar air optimum ( $\left.\mathrm{w}_{\mathrm{opt}}\right)$ tanah

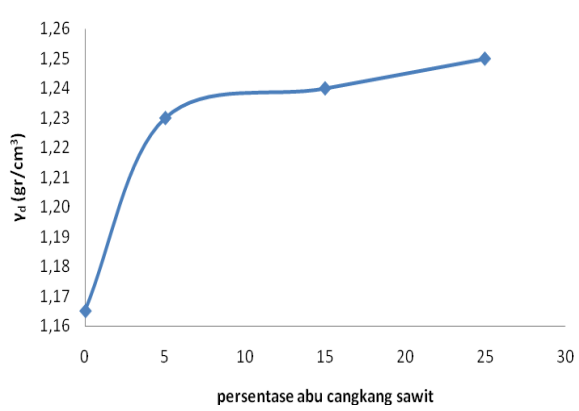

Gambar 9. Pengaruh abu cangkang sawit terhadap berat volume kering $\left(\gamma_{d}\right)$ tanah

Pada campuran $25 \%$ abu cangkang sawit dalam tanah, kadar air optimum $\left(\mathrm{w}_{\mathrm{opt}}\right)$ meningkat sebesar $16,23 \%$ atau $73,77 \%$ dari kadar air optimum ( $\mathrm{w}_{\mathrm{opt}}$ ) tanah asli, dan nilai berat kering maksimum ( $\left.\gamma_{\text {maks }}\right)$ meningkat sebesar $0,085 \mathrm{gr} / \mathrm{cm}^{3}$ atau $7,30 \%$ dari nilai berat kering maksimum $\left(\gamma_{\text {maks }}\right)$ tanah asli. Meningkatnya kadar air optimum ini disebabkan karena pengaruh serapan air oleh abu cangkang sawit. Pada uji batas cair $(L L)$, terlihat nilai ini cenderung turun seiring dengan meningkatnya persentase abu cangkang sawit dalam tanah. Hal ini menggambarkan daya ikatan air pada tanah berkurang, sehingga sebagian air pori mudah meninggalkan rongga pori saat proses pemadatan dan rongga tersebut diisi oleh butiran tanah. Akibatnya butiran semakin merapat dan rongga pori semakin mengecil dan tanah semakin padat.

Hasil uji kuat tekan menunjukan, nilai kuat tekan rata-rata batubata cenderung meningkat seiring dengan bertambahnya persentase abu cangkang sawit dalam 
kandungan tanah pembuat batubata Tabel 9,

Gambar 10. Pada 25\% abu cangkang sawit dalam tanah, nilai kuat tekan adalah 121,20 $\mathrm{kg} / \mathrm{cm}^{2}$. Jika dibandingkan dengan batubata tanpa abu cangkang sawit, terjadi peningkatan kuat tekan sebesar $58,91 \mathrm{~kg} / \mathrm{cm}^{2}$ atau $94,57 \%$ dari kuat tekan batubata tanpa kandungan abu cangkang sawit.

Meningkatnya nilai kuat tekan ini disebabkan karena keberadaan abu cangkang sawit dalam campuran tanah dapat meningkatkan kepadatan tanah.

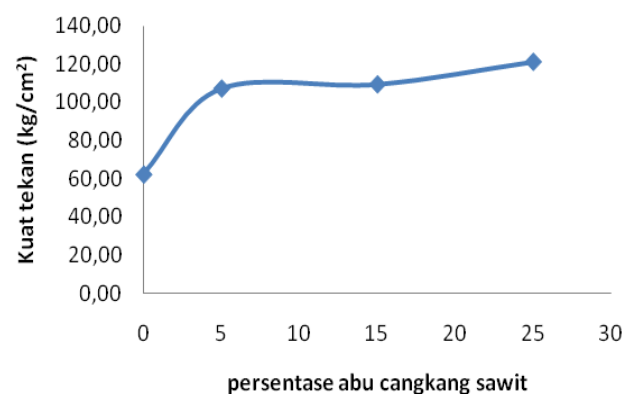

Gambar 10. Pengaruh abu cangkang sawit terhadap kuat tekan batubata

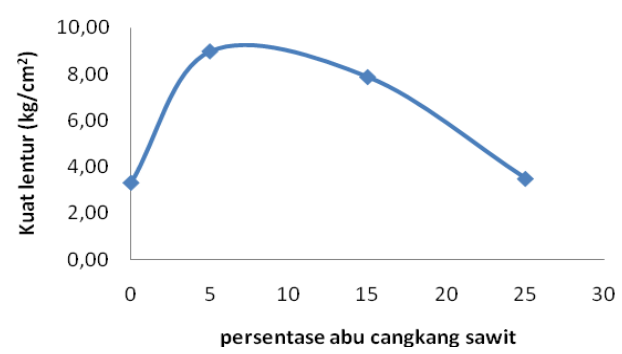

Gambar 11. Pengaruh abu cangkang sawit terhadap kuat lentur batubata

Sedangkan uji kuat lentur pada batubata Tabel 10, Gambar 11, menunjukan, pada awalnya nilai ini meningkat, seiring dengan meningkatnya persentase abu cangkang sawit pada tanah pembuat batubata, nilai kuat lentur batubata ini cenderung menurun. Nilai kuat lentur maksimum dicapai pada kandungan 5\% abu cangkang sawit dalam batubata. Pada kondisi ini nilai kuat lentur meningkat sebesar 5,67 $\mathrm{kg} / \mathrm{cm}^{2}$ atau $171,82 \%$ dari kuat lentur bata dengan tanah asli. Sedangkan 25\% abu cangkang sawit dalam kandungan batubata, nilai kuat lentur batubata $3,47 \mathrm{~kg} / \mathrm{cm}^{2}$ hampir sama dengan nilai kuat lentur batubata dengan tanah asli. Meningkatnya kandungan abu cangkang sawit dalam kandungan batubata, membuat batubata cenderung menjadi kaku dan getas karena menurunnya sifat elastisitas batubata. Hal ini terlihat pada uji Atterberg dimana abu cangkang sawit dapat menurunkan platisitas tanah.

Persentase kandungan abu cangkang sawit dalam batubata yang paling baik pada penelitian ini adalah 5\% abu cangkang sawit dalam kandungan tanah pembuat batubata.

\section{KESIMPULAN DAN SARAN.}

\section{Kesimpulan}

Berdasarkan hasil penelitian dan pembahasan diatas dapat diambil kesimpulan sebagai berikut :

1. Tanah dasar pembuatan batubata yang diambil dari desa Gunung Sariak Padang ini adalah jenis tanah yang masuk dalam kelompok $M H$ atau lanau anorganik dengan plastisitas tinggi (USCS). 
2. Hasil uji sifat-sifat fisis tanah menunjukan bahwa keberadaan abu cangkang sawit pada tanah bahan pembuatan batubata, dapat meningkatkan kandungan butiran kasar tanah, nilai gravitas khusus dan menurunkan sifat plastisitas tanah.

3. Hasil uji sifat mekanis tanah menyimpulkan bahwa abu cangkang sawit dapat meningkatkan nilai kepadatan tanah.

4. Hasil uji kuat tekan batubata, abu cangkang sawit dapat meningkatkan nilai kuat tekan rara-rata batubata, pada persentase $25 \%$ abu cangkang sawit dalam kandungan tanah, nilai kuat tekan rata-rata batubata meningkat sebesar 94,57\% dari kuat tekan rata-rata batubata dengan tanah asli. Sedangkan hasil uji kuat lentur, pada awalnya nilai ini naik, seiring dengan meningkatnya kandungan abu cangkang sawit dalam tanah, nilai kuat lentur ini cenderung menurun. Nilai maksimum dicapai saat pencampuran tanah dengan 5\% abu cangkang sawit, dimana terjadi peningkatan sebesar $171,82 \%$ dari kuat lentur batubata dengan tanah asli.

5. Berdasarkan hasil uji kuat tekan dan kuat lentur ini terhadap batubata, maka nilainilai terbaik diperoleh pada kandungan 5\% abu cangkang sawit dalam campuran tanah pembuat batubata.

\section{Saran}

Dari penelitian yang telah dilakukan, kiranya ada beberapa saran demi dicapainya hasil penelitian yang lebih baik, diantaranya ;

1. Perlu penelitian lainnya untuk menggunakan bahan additive yang berbeda kedalam tanah pembuatan batubata, dengan campuran dan masa perawatan yang lebih bervariasi dalam upaya meningkatkan mutu batubata.

2. Agar penelitian berikutnya menggunakan Standar Nasional Indonesia (SNI) tentang mutu batubata sebagai acuan, sehingga pengujian dan hasil pengujian yang dicapai dapat dibandingkan dengan standar mutu yang ada.

\section{DAFTAR PUSTAKA}

Anonim, 1992, Annual Book of ASTM Standarts, Section 4, Volume 04 08, Philadelphia,USA

Fathani, T.F., dan Adi, A.D., 1999, "Perbaikan Sifat Lempung Ekspansif dengan Penambahan Kapur", Prosiding Seminar Nasional Geoteknik'99' hal.97-105.

Fernanda A. Dkk, "Studi Kekuatan Pasangan Batubata Paska Pembakaran Menggunakan Bahan Additive Zeolit", JRSDD. Vol. 1, No. 1, Edisi Desember 2012.

Indra, A. Dkk, "Pengaruh Temperatur Pembakaran Pada Komposit Lempung I RHA, Terhadap Sifat Mekanik (Aplikasi pada Bata Merah)", Prosiding Seminar Nasional Mesin dan Industri (SNMI VIII) 2013 
Das, B.M, 1998,"Mekanika Tanah (Prinsipprinsip Rekayasa Geoteknik)", Penerbit Erlangga, Jakarta.

Hardiyatmo, H.C, 2012, "Mekanika Tanah I dan II", Gadjah Mada University Press, Yogyakarta

Handayani, S., 2010, "Kualitas Batubata Merah Dengan Penambahan Serbuk Gergaji”, Jurnal Teknik Sipil Dan Perencanaan No. 1 Vol. 12, Januari 2010.

Hernandes, R., 2012, "Pengaruh Penambahan Silika RHA pada Komposit Lempung / Silika Terhadap Kuat Tekan", Tugas Akhir Strata I, Institut Teknologi Padang.

Hutahaen, B., 2007, "Pengujian Sifat Mekanik Beton Yang Dicampur Dengan Abu Cangkang Sawit", Skripsi Jurusan Fisika, FMIPA INIMED, Medan

Ingles, O.G. dan Metcalf, J.B., 1992, "Soil Stabilitzation Principles and Practice", Butterworths Pty. Limited, Melbourne.

Maidiawati, Yasushi Sanada (2016), " $R / C$ Frame-Infill Interaction Model and Its application to Indonesian Buildings", Earthquake Engineering \& Structural Dynamics. DOI: 10.1002/eqe.2787

Munasih, dkk, 2016 "Batubata Dengan Campuran Abu Sekam Padi Di Desa Saptorenggo, Kecamatan Pakis, Kabupaten Malang", Industri Inovatif Vol. 6, No. 1, Maret 2016

Raharjo, MT, dkk, 2015 "Pengaruh Penggunaan Abu Vulkanik Sebagai Pengganti Sebagian Tanah Liat Pada Batu Bata Terhadap Kuat Tekan , Berat Jenis Dan Daya Resapan Air Sebagai Pendalaman Materi Konstruksi Bangunan DI SMK Teknik Bangunan", www.jurnal.fkip.uns.ac.id
Setiawan, D., "Bata Merah Vs Bata Ringan :Okezone Ekonomi" economy.okezone.com/read/2012/05/1 9/472/632002/bata-merah-vs-bataringan, 23 Maret 2016

Surta, RNP. "Pengaruh Waktu Pemeraman Terhadap Nilai Kohesi Tanah Mengembang Yang Distabilisasi dengan Abu Cangkang Sawit", Jurnal Ilmiah Sipil, Arsitektur, dan Planologi Vol 1 no. 1, mei 2012 